\title{
First Year Engagement \& Retention: A Goal-Setting Approach
}

\author{
David Tuffley \\ Griffith University, \\ Brisbane, QId., Australia \\ D.Tuffley@griffith.edu.au
}

\author{
Amy Antonio \\ University of Southern Queensland, \\ Toowoomba, QId., Australia
}

\section{Amy.Antonio@usq.edu.au}

\section{Executive Summary}

First year students face a daunting range of challenges as they make the transition to university life. Their experiences in the first months of university have a defining influence on their success or otherwise in their studies. The purpose of this paper is to report on the results of a case study that tests the efficacy of a student engagement and retention strategy aimed at first year students. The strategy encourages self-reflection and goal-setting by encouraging them to think constructively about their ideal future career. Once created, this idea is reinforced to become a firm goal. The student's perception of university study is thus reframed from being an end in itself to being a means to an end. Instead of perceiving the future as endless assignments and exams, they see themselves moving purposefully towards their ideal career.

This paper, therefore, describes a three-stage case study that explores the effectiveness of this engagement strategy with a cohort of 258 demographically-diverse first-year ICT students enrolled in a Bachelor of IT program. In the first stage of the strategy, the lecturer spends 20 minutes of the first four lectures presenting material across a range of cutting-edge technology topics. In addition to this, the characteristics of high-performing IT professionals are elucidated. The objective of this stage is to paint a picture of a creative, high-performing practitioner who is producing cutting-edge work. In the second stage, an assessment item is set in which the students explore their ideal career using a Web 2.0 digital curation tool; in the third stage, a series of three questionnaires are administered, the results of which are analysed to determine the students' attitude towards the engagement strategy.

In the final analysis, $\mathbf{6 3 . 4 \%}$ of students surveyed indicated that the exercise had helped them to become more committed to finishing their degree program. It is suggested that this strategy could be generalised to work with other disciplines besides information technology.

Material published as part of this publication, either on-line or in print, is copyrighted by the Informing Science Institute. Permission to make digital or paper copy of part or all of these works for personal or classroom use is granted without fee provided that the copies are not made or distributed for profit or commercial advantage AND that copies 1) bear this notice in full and 2) give the full citation on the first page. It is permissible to abstract these works so long as credit is given. To copy in all other cases or to republish or to post on a server or to redistribute to lists requires specific permission and payment of a fee. Contact Publisher@InformingScience.org to request redistribution permission.
The results are sufficiently encouraging for a formal follow-up study to be performed in two and a half years, when this cohort are nearing the end of their degree program, to determine what longer term effect the engagement and retention strategy might have had on the students' commitment to their study. 
Keywords: First year experience, student retention in higher education, engagement strategy, goal-setting, self-reflection.

\section{Introduction}

First year university students have distinct learning needs that arise from the social and academic transition they are experiencing. They are "on a journey to becoming self-managing and selfdirected learners and the first year curriculum should help them get there" (Wong, 2013, p. 130).

This case study is a formal implementation of an ad hoc strategy employed by the Griffith author in his role as a first year course convenor/lecturer over the previous ten years. Anecdotal evidence and feedback from the formal course evaluation questionnaires suggested the engagement strategy employed in this research might be effective, though there was little empirical evidence to support this. The case study therefore collects quantitative and qualitative data to evaluate the efficacy of this strategy.

The primary purpose of the strategy is aimed at fostering student engagement. Factors such as student involvement with peers, lecturers, and the larger university community all contribute to a student's sense of engagement. This paper looks beyond the well-studied extrinsic factors that contribute to engagement to the intrinsic factors of self-reflection and goal-setting. The operative rationale here is that the students are encouraged to envisage their ideal future career, and the sense of anticipation and positive regard that this creates then helps them to develop a strong sense of purpose and commitment to finishing their program. According to Tabor and Minch (2013), teaching in the area of ICT offers many opportunities to incorporate technology into the classroom, which not only teaches students about technology but also assists them in the acquisition of useful business skills that will, potentially, enhance their interest in life-long learning. Building on this premise, it was proposed that the integration of the digital curation tool Scoop.it into the first year Information Communication Technology (ICT) curriculum would increase students' engagement and their investment in their own learning journey which would, in turn, enable the students to think systematically about their ideal career. Digital curation is an emerging discipline (Yakel, 2007) that may prove to be useful in an educational context.

\section{Student Engagement through Goal-Setting}

If a student is to successfully complete his or her studies, it is necessary to cultivate motivation and commitment. These can be described as intrinsic engagement factors. The demands of tertiary-level study require students to operate in a more self-directed, autonomous way. A tertiary student needs to make the transition from being directed primarily by external authority figures, to become a self-directed learner at university. Manochehri and Sharif (2010) measured students' attitudes towards learning with various classroom technologies and found that technology increased students' capacity for self-directed learning, which was related to student perceptions of the relevance of the learning experience. The findings of this research suggest that in order to enhance student engagement, the relevance of the task to their future career needs to be apparent.

Furthermore, the degree of engagement exhibited by a student is recognized as a factor contributing to his or her success (Kuh, 2002). A student's greater involvement in university life has been shown to produce a more determined approach to his or her studies which in turn leads to a greater sense of satisfaction (Astin, 1993; Pascarella \& Terenzini, 2005). A positive feedback loop is created that leads to the reinforcement of a student's behavior which in turn leads eventually to success.

Involvement with other students, lecturers, and the university community at large are external factors. Arguably though, internal engagement factors are just as important as external factors, if not more so. Self-management, for example, is recognised as a contributing factor to student en- 
gagement. Krause (2005) recommends the development of self-management strategies to enhance student engagement in the first year. She suggests that it is desirable for students to become resilient, highly motivated, self-regulated learners who drive their own engagement behaviours. In more specific terms, Chapman (2003) defines engagement as a student's cognitive investment in, active participation in, and emotional commitment to his or her learning.

In this project, student engagement was encouraged by giving students an assessment task that was designed to increase their emotional investment in their own learning journey. The method involves having the students think systematically about their ideal future career. The student motivates him/herself by developing a clear vision of their ideal future job which they adopt as a definite goal. The strategy being tested in this project argues that the enthusiasm and direction thus generated is likely to give students greater momentum that helps them overcome the obstacles that they will encounter as they progress through their degree.

Some earlier research on engagement has focussed on how particular Web 2.0 technologies, such as social networking tools, can be used to create interactive and engaging learning experiences (Ebner, Lienhardt, Rohs, \& Meyer, 2010; Junco, Heiberger, \& Loken, 2010; Wong, 2013;) or, alternatively, on the ways in which tasks that promote higher-order thinking can be utilised to engage higher education students (Coates et al., 2008; Hockingsm, Cooke, Yamashita, McGinty, \& Bowl, 2008; Laird \& Kuh, 2005).

\section{Contrast between Current State and Desirable Future State}

The approach taken in this case study involves creating an aspirational contrast between one's current state and a more desirable future state. The question for self-reflection is asked: here is where I am now, where do I want to be in five to ten years? The student, who is likely to already be aspirationally primed at the beginning of his/her university studies, is encouraged to actively visualise this desirable future state and make an emotional investment in it.

The speaker then reiterates the contrast between current and future states several more times during the lecture. It is reasoned that the audience will develop an increasing desire for that future state as a result of the exercise. While this technique has its origins in classical rhetoric, in the context of higher education engagement, it can be understood as the practice of self-reflective goal-setting.

Erez and Judge (2001) observed that a student's set of core beliefs is directly related to the goalsetting behaviour he/she engages in. A clearly formulated goal that is earnestly desired and reinforced often gives the student a strong sense of purpose. The importance of clear goal-setting is emphasised by Pitkethly and Prosser's 2001 study in which it was concluded that students fail or withdraw from university as a result of either a failure to adjust or else the effect of negative environmental factors, the primary one of which is lack of clearly defined goals. Goals can be differentiated into mastery - the aim to improve one's ability, understanding, or competence in a subject learnt - and performance goals - the aim to demonstrate normative competence (Barron \& Harackiewicz, 2001). While the relative importance of each of these goals is the subject of ongoing debate, there are benefits to both kinds of goal-oriented behaviours, thus providing support for a multiple goal perspective (Barron \& Harackiewicz, 2001).

The endogenous student engagement strategy presented in this paper adheres to this multiple goal model by engendering the development of a self-image that involves high degrees of both mastery and performance goals: the students improve their understanding of their topic (mastery goals) by engaging with the most up-to-date literature in the area and, subsequently, see themselves as high-performing practitioners in that field (performance goals). 


\section{Methodology}

\section{Case Study}

The case study approach used in this project is well-suited to the educational context (Gulsecen \& Kubat, 2006). Action research was considered as an alternative method, but there was insufficient opportunity to perform reiterative improvements and test their effectiveness. Another limitation was the absence of solid baseline data against which to evaluate the current data.

Given access to a large and demographically diverse cohort of first year students, a case study was devised that investigated a phenomenon in its real-life context. The study included quantitative and qualitative data derived from multiple sources (Yin, 2009) and was informed by earlier theoretical work in the area of student engagement.

\section{Conduct}

258 university students from a first year, first semester Communications for ICT course constituted the participants of this study. The course was presented across three demographically diverse campuses of a metropolitan university in Australia. One campus is in a low SocioEconomic Strata (SES), one in a low to middle SES, and one in middle to high SES. Approximately $90 \%$ of students are male. Approximately $60 \%$ of students are domestic, while $40 \%$ are international students.

The research method involved three distinct stages. The first was the application of the selfreflective goal-setting technique described in the previous section. This involved asking the students to consider where you are now, [and] where do you want to be in five to ten years? The second stage involved the integration of an assessment task in which the students were required to express their career aspirations by producing a virtual presentation of content pertaining to the topic they were interested in pursuing in their career. In stage three, the students were asked to complete three surveys and the results were subsequently analysed.

In Stage 1, the lecturer spent the first 20 minutes of the first four lectures presenting material across a wide range of interesting, if not inspiring topics. In these sessions the characteristics of high-performing IT professionals were explained, cutting edge technologies were showcased, and motivation was hopefully generated for students to pursue similar career paths to those that were on display. The question was repeatedly asked, though in differing ways; do you have a clear idea of what your ideal future career looks like? The question was placed in the context of try to observe the patterns of development of the recent past and extrapolate these into the future. Use this information to proactively position yourself to take advantage of that future when it arrives, rather than wait and then act.

In Stage 2, the students were given an assessment task which was divided into two parts. Part A, due at end of week 4 , asked the students to produce a graphically-rich presentation using a webbased digital curation tool (Scoop.it in this case). This task involved searching a wide variety of available on-line sources (library, Google Scholar, web) and curating those sources into a graphically rich presentation. The students had to collect a minimum of five pieces of digital content pertaining to their chosen topics and submit the Scoop.it URL to the course lecturer at the end of week 4 . Moreover, the presentation could be shared with others and was publishable on social media sites like Facebook.

Part B, which was due in week 6 , required the students to complete a 1,000 word essay that was a continuation of the first part of the assignment. The students had a choice between two essay topics, each with a slightly different focus: Topic option 1: Based on current trends in the IT industry, what might be the five most important technologies in the next 5 to 10 years? Or topic option 
2: Based on your chosen field, research what developments are likely in that field in next 5 to 10 years? The first option was intended to clarify the aspirations of students who were unsure of their chosen field and the second option was for those with a clearer idea of their future career.

Part A was worth 10 marks while Part B, the essay writing task, was worth 20 marks. Part A was designed to be enjoyable and to engage weaker students who might otherwise be unsure of their ability to complete assessment tasks, while at the same time encouraging them to clarify their career aspirations. Part B aligned with institutional requirements for the inclusion of a formal writing task within the curriculum.

In Stage 3, after the assessment items had been submitted, marked, and returned with feedback, the students were surveyed on their experience of the Scoop.it and essay writing tasks.

The following introduction, which provided orientation for the survey, was sent as a broadcast email to all students enrolled in the course. If you have been attending lectures, you will know that I have been spending some time trying to help you to clarify your career aspirations by imagining your ideal career. I'm thinking that doing this will help you to find the motivation to complete your studies (if you needed it).

Survey content is shown below. The survey data thus derived was downloaded and analysed as presented in the Results. A follow up survey was distributed two weeks later, which aimed to assess whether or not the engagement technique employed throughout the course had assisted students in clarifying their career goals. A final survey was conducted four months after the course was finished, seeking an answer to the question: To what extent did imagining your ideal future career in IT help you to become more committed to finishing your Bachelor of IT?

\section{Data Collection Methods}

To maximise the usefulness of the results, three sets of data were collected. By a process of triangulation (Jick, 1979) the results of these data collection methods might be compared against the other, helping to validate or invalidate them.

- First Questionnaire. Following completion of the assessment item in week 4, students were asked to complete a comprehensive questionnaire on the experience. The anonymous survey was designed with Qualtrics and disseminated online. While the overall survey included additional questions, one question specifically asked students to assess the extent to which the Scoop.it task had helped them clarify their career goals.

- Second Questionnaire. In week 6, a shorter survey questionnaire was administered to determine if students' attitudes towards their ideal career had evolved and to clarify certain questions raised in the analysis of the first questionnaire. While the first questionnaire consisted of 21 questions that were designed to assess the students' experience of the Scoop.it assessment task, including how they engaged with the platform and whether or not it helped them to determine a career path, the second survey was designed specifically to assess the extent to which Scoop.it had helped the students clarify their career aspirations.

- Third Questionnaire. Four months after the course finished, a one question survey was sent to course enrolees seeking an answer to the question: To what extent did imagining your ideal future career in IT help you to become more committed to finishing your Bachelor of IT?

It was felt that using three data sources would serve to indicate a general trend which might be helpful to off-set the effects of students not giving sufficient thought to their survey answers, and 
also the possibility of selection bias, given the relatively small number of respondents $(n=84$, $\mathrm{n}=45, \mathrm{n}=71$ ) to the three questionnaires.

In each questionnaire, the students were emailed with a link to an electronic survey. The students were asked to indicate "To what extent do you agree or disagree with the following statements?" Answers were rated on a five point Likert scale ranging from Strongly Disagree (1) to Strongly Agree (5). When interpreting the responses to the Likert-scale items, student responses for Strongly Agree and Agree were collapsed into a single "agree" category, while Strongly Disagree and Disagree were similarly combined as "disagree".

\section{Results}

\section{First Questionnaire}

Of the 258 active enrolments, a total of 84 students participated in the non-compulsory survey, yielding a participation rate of $32.5 \%$.

The first questionnaire was primarily aimed at evaluating the efficacy of the Web 2.0 digital curation tool (Scoop.it), which formed part of the engagement strategy, and replaced the formal essay that was previously used. Table 1 illustrates the students' responses.

Table 1: (First questionnaire) Student responses to the question:

To what extent do you agree or disagree with the following statements $(\mathrm{n}=84)$

\begin{tabular}{|l|c|c|c|c|c|c|}
\hline Question & S Disagree & Disagree & $\begin{array}{c}\text { Neu- } \\
\text { tral }\end{array}$ & Agree & S Agree & Average \\
\hline $\begin{array}{l}\text { The use of Scoop.it has helped me } \\
\text { clarify my career goals. }\end{array}$ & $9.3 \%$ & $20.2 \%$ & $23.8 \%$ & $36.5 \%$ & $9.3 \%$ & $\mathbf{3 . 1 3}$ \\
\hline $\begin{array}{l}\text { The use of Scoop.it has helped me } \\
\text { determine the areas of ICT I am inter- } \\
\text { ested in. }\end{array}$ & $9.3 \%$ & $14.2 \%$ & $23.2 \%$ & $45.4 \%$ & $9.3 \%$ & $\mathbf{3 . 3 8}$ \\
\hline $\begin{array}{l}\text { As a result of using Scoop.it, I have } \\
\text { discovered areas of ICT that I was pre- } \\
\text { viously unaware of. }\end{array}$ & $9.3 \%$ & $9.3 \%$ & $22.8 \%$ & $38.9 \%$ & $18.2 \%$ & $\mathbf{3 . 4 2}$ \\
\hline
\end{tabular}

\section{Second Questionnaire}

The second survey was designed to further explore the issue of whether using Scoop.it had helped the students to clarify their career aspirations. Of the 258 students enrolled in the course, a total of 45 participated in the second non-compulsory survey, yielding a participation rate of $17.6 \%$. This comparatively low response rate may have been due to survey fatigue after several earlier surveys administered by the university (Student Evaluation of Course, and of Teaching).

In the second survey, the students were again asked to indicate the extent to which they agreed with the following statements:

Q1. When I started my degree I had a clear idea of what my ideal future career would be.

Q2. After doing Communications for ICT, I now have a clear idea of my future career.

Q3. It helped me to be presented with a range of inspiring topics in which the characteristics of high-performing IT professionals are explained and cutting edge technologies are show-cased. 
Q4. It helped me to envisage the future by observing the patterns of development of the recent past and to extrapolate these into the future.

Table 2 shows the students' responses to these statements. On the five point rating scale, Strongly Disagree had a value of one, and Strongly Agree a value of five.

Table 2: (Second questionnaire) Student responses to Likert-scale questions $(n=45)$

\begin{tabular}{|l|c|c|c|c|c|c|}
\hline & S Disagree & Disagree & Neutral & Agree & S Agree & Average \\
\hline Q1 & $6.7 \%$ & $20.0 \%$ & $28.9 \%$ & $35.6 \%$ & $8.9 \%$ & $\mathbf{3 . 2 0}$ \\
\hline Q2 & $2.2 \%$ & $11.1 \%$ & $26.7 \%$ & $48.9 \%$ & $11.1 \%$ & $\mathbf{3 . 5 6}$ \\
\hline Q3 & $2.3 \%$ & $2.3 \%$ & $11.4 \%$ & $59.1 \%$ & $25.0 \%$ & $\mathbf{4 . 0 2}$ \\
\hline Q4 & $2.2 \%$ & $4.4 \%$ & $15.6 \%$ & $57.8 \%$ & $20.0 \%$ & $\mathbf{3 . 8 9}$ \\
\hline
\end{tabular}

Each question also afforded the opportunity for respondents to comment in free form text. Table 3 gives indicative responses across the range of positive, negative and neutral. The weighting of these responses followed the general trend of the average of the numerical responses shown in Table 2.

Table 3: (Second questionnaire) Student responses to free-form text questions $(n=45)$

\begin{tabular}{|c|c|c|c|}
\hline & Positive & Neutral & Negative \\
\hline Q1 & $\begin{array}{l}\text { I knew the areas I was already } \\
\text { interested in, but I was (and am) } \\
\text { very open to discovering new } \\
\text { things that I'd never thought to be } \\
\text { interesting before, even to maybe } \\
\text { finding out what I thought I was } \\
\text { interested in wasn't so engag- } \\
\text { ing....anything! }\end{array}$ & $\begin{array}{l}\text { I came with a fairly open } \\
\text { mind, not yet knowing what } \\
\text { my major should be but rec- } \\
\text { ognising my current interests }\end{array}$ & $\begin{array}{l}\text { I knew what I wanted to do } \\
\text { and I still do. But made ex- } \\
\text { cuses why I did not follow } \\
\text { that path }\end{array}$ \\
\hline Q2 & $\begin{array}{l}\text { Our first assignment got us think- } \\
\text { ing about emergent technologies. } \\
\text { Having to research these areas I } \\
\text { quickly realised the field that in- } \\
\text { terested and fascinated me the } \\
\text { most. }\end{array}$ & $\begin{array}{l}\text { Its the same as it was before } \\
\text { hand }\end{array}$ & $\begin{array}{l}\text { This course has not intro- } \\
\text { duced new career choices to } \\
\text { me, thus not assisting me in } \\
\text { deciding on potential ca- } \\
\text { reers. }\end{array}$ \\
\hline Q3 & I would have liked more of this. & $\begin{array}{l}\text { This was certainly highly valu- } \\
\text { able, but as per previous } \\
\text { comment, broadened the } \\
\text { horizon rather than focused } \\
\text { it. }\end{array}$ & $\begin{array}{l}\text { Unfortunately I did not find } \\
\text { any of the professionals } \\
\text { shown in the TED talks to be } \\
\text { inspiring - they all seemed to } \\
\text { be a little too 'high and } \\
\text { mighty' for my liking. Yeah I } \\
\text { get it, you wrote a book or } \\
\text { once was the secretary to a } \\
\text { CEO of a large company - } \\
\text { there are thousands of peo- } \\
\text { ple across the world in simi- } \\
\text { lar situations. You are not } \\
\text { inspiring - you just worked } \\
\text { hard, that's all. }\end{array}$ \\
\hline Q4 & & $\begin{array}{l}\text { Also to see how industry vi- } \\
\text { sionaries are assembling their } \\
\text { vision of the future. }\end{array}$ & $\begin{array}{l}\text { I believe by reflecting on past } \\
\text { inventions will only hinder \& } \\
\text { limit creativity }\end{array}$ \\
\hline
\end{tabular}




\begin{tabular}{|l|l|l|l|}
\hline $\begin{array}{l}\text { This course has helped me finalize } \\
\text { some key points in choosing my } \\
\text { future career in IT, especially as } \\
\text { the scope of IT is extensively } \\
\text { broad. Completing the tasks has } \\
\text { helped me focus and encourage } \\
\text { me to fulfill my desired career. }\end{array}$ & $\begin{array}{l}\text { This course was like no other } \\
\text { more courses were like this }\end{array}$ & Overall a good course \\
\hline
\end{tabular}

\section{Third Questionnaire}

The third survey was designed to further explore the issue of whether the retention strategy had helped the students to become more committed to finishing their degree. Of the 258 students enrolled in the course, a total of 71 participated in the third non-compulsory survey, yielding a participation rate of $27.5 \%$. As with the second questionnaire, this comparatively low response rate may have been due to survey fatigue after several earlier surveys administered by the university (Student Evaluation of Course, and of Teaching).

On the five point rating scale, Strongly Disagree had a value of one, and Strongly Agree a value offive. Table 4 shows the students' responses to these statements.

In the third survey, the students were again asked to indicate the extent to which they agreed with the following statement:

Q1. To what extent did imagining your ideal future career in IT help you to become more committed to finishing your Bachelor of IT?

Table 4: (Third questionnaire) Numerical responses $(n=71)$

\begin{tabular}{|l|l|l|l|l|l|l|}
\hline & S Disagree & Disagree & Neutral & Agree & S Agree & Average \\
\hline Q1 & $8.5 \%$ & $4.2 \%$ & $23.9 \%$ & $33.8 \%$ & $29.6 \%$ & $\mathbf{3 . 7 2}$ \\
\hline
\end{tabular}

Respondents were also able to make an optional comment in free form text. Table 5 gives the total of sixteen responses across the range of positive, negative and neutral.

Table 5: (Third questionnaire) Full text responses $(n=71)$

\begin{tabular}{|l|l|l|l|}
\hline \multicolumn{1}{|c|}{ Positive } & \multicolumn{1}{c|}{ Neutral } & \multicolumn{1}{c|}{ Negative } \\
\hline $\begin{array}{l}\text { It was inspiring, but I ended up } \\
\text { changing where I think I'd like to } \\
\text { be in the future. Haven't changed } \\
\text { my level of commitment thus far. } \\
\text { from a different point of } \\
\text { view. }\end{array}$ & $\begin{array}{l}\text { The assignment prompted } \\
\text { jects in greater detail and } \\
\text { frook at IT related sub- }\end{array}$ & $\begin{array}{l}\text { I don't think it made me } \\
\text { more committed to finishing } \\
\text { - I was completely commit- } \\
\text { ted when I started even } \\
\text { though I didn't have a clear } \\
\text { direction. However it did } \\
\text { make me realize I needed to } \\
\text { start thinking about what } \\
\text { direction I was going to go } \\
\text { during (and after) the } \\
\text { course. It made me think } \\
\text { about what I liked and was } \\
\text { interested in... and then re- } \\
\text { searched some of those } \\
\text { things. }\end{array}$ \\
\hline
\end{tabular}




\begin{tabular}{|c|c|c|}
\hline $\begin{array}{l}\text { To be completely honest Imagin- } \\
\text { ing my ideal future career in the IT } \\
\text { industry, it kind of increased my } \\
\text { commitment and interest in stay- } \\
\text { ing at university. }\end{array}$ & $\begin{array}{l}\text { It helps but sometimes you } \\
\text { just want to stop because it } \\
\text { gets hard at some points. }\end{array}$ & $\begin{array}{l}\text { Having previously worked in } \\
\text { the IT industry I have no de- } \\
\text { sire to continue in this line of } \\
\text { work and am continuing my } \\
\text { bachelor only because I'm } \\
\text { more than half way through. }\end{array}$ \\
\hline $\begin{array}{l}\text { I am pretty sure that I would like } \\
\text { to write things like User Manuals } \\
\text { when I leave university! Doing this } \\
\text { course definitely helped me real- } \\
\text { ize that.! }\end{array}$ & & $\begin{array}{l}\text { I was } 100 \% \text { committed in the } \\
\text { first place and still am. }\end{array}$ \\
\hline $\begin{array}{l}\text { The more I had to research areas } \\
\text { of interest the more interested in } \\
\text { an area I became. }\end{array}$ & & \\
\hline $\begin{array}{l}\text { allowed me to further my reasons } \\
\text { for study and encouraged me to } \\
\text { succeed }\end{array}$ & & \\
\hline $\begin{array}{l}\text { It helps to refocus you on your } \\
\text { goals. }\end{array}$ & & \\
\hline $\begin{array}{l}\text { It will allow me to select my major } \\
\text { easier. }\end{array}$ & & \\
\hline $\begin{array}{l}\text { The assignment prompted me to } \\
\text { look at IT related subjects in } \\
\text { greater detail and from a different } \\
\text { point of view. }\end{array}$ & & \\
\hline $\begin{array}{l}\text { I was already committed, but it } \\
\text { assisted in whittling down exactly } \\
\text { what I wanted to major in and aim } \\
\text { for as a future career. }\end{array}$ & & \\
\hline $\begin{array}{l}\text { The more I had to research areas } \\
\text { of interest the more interested in } \\
\text { an area I became. }\end{array}$ & & \\
\hline $\begin{array}{l}\text { It helped to decide on which di- } \\
\text { rection to go, however it also } \\
\text { made it seem more foreboding. }\end{array}$ & & \\
\hline $\begin{array}{l}\text { If you want to do something, you } \\
\text { always need to have a plan. } \\
\text { The exercise gave us the chance } \\
\text { to really sit down and think about } \\
\text { what we want to do in our ca- } \\
\text { reers. It helped a lot to get our } \\
\text { minds warmed up at the start of } \\
\text { university. Great! }\end{array}$ & & \\
\hline $\begin{array}{l}\text { Only if i want a career in IT in the } \\
\text { future, i can have the motivation } \\
\text { to go ahead acquiring IT knowl- } \\
\text { edge }\end{array}$ & & \\
\hline
\end{tabular}




\section{Discussion}

Three data sources allowed for a triangulated view of the data and strengthen the validity of the findings.

\section{First Questionnaire}

Overall, the quantitative data from the first questionnaire $(n=84)$ supports the view that the strategic approach taken in this project was successful at helping students clarify their career goals with $45.8 \%$ of respondents agreeing that the exercise had helped them to do this. It might have been expected that this figure would be higher. However, given that approximately half of the enrolled students attended lectures (which are not compulsory) and were thus exposed to the goal-setting exercise, this figure becomes more understandable. This group of positive indicating students may well have been the same group who attended lectures and were exposed to the goal-setting exercise of actively imagining their ideal future career.

\section{Second Questionnaire}

In week 6 (two weeks after the first), a second questionnaire was administered. The results of the second survey $(n=45)$ suggest that the goal-setting retention strategy was somewhat effective, with $60.0 \%$ of students saying they now had a clearer idea of their future career and $26.7 \%$ being neutral on the question.

Furthermore, in response to the goal-setting exercise delivered in lectures, $84.1 \%$ said it was helpful to be shown a range of inspiring topics in which the characteristics of high-performing IT professionals were explained and cutting edge technologies showcased.

\section{Third Questionnaire}

The third questionnaire $(\mathrm{n}=71)$ asked the students, with the benefit of hindsight: To what extent did imagining your ideal future career in IT help you to become more committed to finishing your Bachelor of IT? This is the capstone question of the case study.

$63.4 \%$ of respondents indicated that the strategy had made them more committed to finishing their degree. $23.9 \%$ were neutral on the question, while $12.7 \%$ said it had not helped.

Thirteen out of the sixteen qualitative responses were positive, two were neutral and three were negative. One negative commenter contradicted himself, saying at first that it had not helped at all, then going on to say that it had helped by making him think carefully about his future direction. The second negative comment indicated that the respondent started out with no intention of pursuing a career in IT, he simply wanted to finish his degree. The third negative comment indicated that the respondent was already $100 \%$ sure of what he wanted to do.

The two neutral comments indicated a somewhat positive attitude despite the neutral score, while the three negative comments appeared to be from possibly mature-aged students who already seemed to have fixed ideas.

With 63.4\% saying the strategy had definitely helped, and the written feedback being overwhelmingly positive, the case can be made that the strategy works. The integration of an assessment task into the curriculum that had real-world relevance increased the students' engagement and encouraged them to think strategically about their careers. This supports previous research in the area which similarly found that students' capacity for self-directed learning was closely intertwined with the perceived relevance of the learning experience to their future goals (Manochehri \& Sharif, 2010). 


\section{Conclusion}

Overall, the results of the questionnaires support the view that the retention strategy was moderately successful. Questionnaire 1 focussed on the efficacy of using a Web 2.0 digital curation tool as an engagement strategy. Questionnaires 2 and 3 were directly related to the research question and are of most interest. They were distributed two weeks and four months after the completion of the Scoop.it assessment task. Table 6 below shows the consolidated responses to the two questionnaires that supports the conclusion.

As a deliberate strategy, three variations of the same basic question were asked and the results compared, as seen in the table below. It will be seen that the results display a relatively consistent result in the combined Agree + Strongly Agree results.

Table 6: Comparison between critical areas of Questionnaires 1, 2 and 3.

\begin{tabular}{|l|l|l|l|l|l|l|}
\hline & S Disagree & Disagree & $\begin{array}{l}\text { Neu- } \\
\text { tral }\end{array}$ & Agree & S Agree & Average \\
\hline $\begin{array}{l}\text { Questionnaire 1: The use of Scoop.it } \\
\text { has helped me determine the areas of } \\
\text { ICT I am interested in (n=84). }\end{array}$ & $9.3 \%$ & $14.2 \%$ & $23.2 \%$ & $45.4 \%$ & $9.3 \%$ & $\mathbf{3 . 3 8}$ \\
\hline $\begin{array}{l}\text { Questionnaire 2: After doing Commu- } \\
\text { nications for ICT, I now have a clear } \\
\text { idea of my future career (n=45). }\end{array}$ & $2.2 \%$ & $11.1 \%$ & $26.7 \%$ & $48.9 \%$ & $11.1 \%$ & $\mathbf{3 . 5 6}$ \\
\hline $\begin{array}{l}\text { Questionnaire 3: To what extent did } \\
\text { imagining your ideal future career in } \\
\text { IT help you to become more commit- } \\
\text { ted to finishing your Bachelor of IT? } \\
\text { (n=71). }\end{array}$ & $8.5 \%$ & $4.2 \%$ & $23.9 \%$ & $33.8 \%$ & $29.6 \%$ & $\mathbf{3 . 7 2}$ \\
\hline
\end{tabular}

An important factor to consider is that it was approximately half of the students enrolled in the course that attended lectures. The other half was therefore not exposed to the full force of the exercise, only the assessment task. This would have had significant bearing on the questionnaire results. Arguably, at least some of the respondents who said the retention exercise did not help them had not been exposed to the full exercise.

While our sample size for each of the three surveys ( $n=84, n=45, n=71)$ was not sufficient to draw strong conclusions about whether or not the exercise had assisted students in clarifying their career aspirations, the results of the three questionnaires nonetheless show a pattern that suggests the retention strategy was helpful. It is not possible to say exactly how helpful it was. Selection bias would have had an effect. To offset this, the case study drew upon three sources of data, each questionnaire asked much the same questions but asked in them using different wording and at different times which allowed for the results to be triangulated.

While this study applied the engagement strategy to IT students, the authors can see no reason why the strategy could not be generalised to other disciplines. To do so would simply require high-achieving exemplars from that discipline to be presented, plus examples of state-of-the-art practice.

An improvement for future research will be to include a question that determines how many of the face-to-face lecture sessions a respondent had attended, plus the respondents' age-bracket and gender. 
As a point of interest, the case study results were consistent with the anecdotal evidence collected from students at the end of the course over the previous ten years, and also from the official Student Evaluation of Course \& Teaching surveys done at the end of every semester.

To conclude, despite the small sample size $(\mathrm{n}=71), \mathbf{6 3 . 4 \%}$ of respondents indicated, four months after the course finished, that the exercise had helped them to become more committed to finishing their degree program, which is a positive indication that the strategy was successful with this cohort of students.

There is therefore some evidence to support the argument that the goal-setting retention strategy used in this project helped students to develop a clearer vision of their future career which made them more committed to finishing their studies. Whether this will prove to be true can only be determined when this cohort reach their final semester. This will be the topic of a later project.

\section{References}

Astin, A. (1993). What matters in college? Four critical years revisited. San Francisco: Jossey-Bass.

Barron, K., \& Harackiewicz, J. (2001). Achievement goals and optimal motivation: Testing multiple goal models. Journal of Personality and Social Psychology, 80(5), 706-722.

Chapman, E. (2003). Alternative approaches to assessing student engagement rates. Practical Assessment, Research and Evaluation, 8(13).

Coates, H., Hillman, J., Jackson, D., Tan, L., Daws, A., Rainsford, D., \& Murphy, M. (2008). Attracting, engaging and retaining: New conversations about learning. Australasian Student Engagement Report (AUSSE), Camberwell: ACER.

Ebner, M., Lienhardt, C., Rohs, M., \& Meyer I. (2010).Microblogs in higher education - A chance to facilitate informal and process-oriented learning. Computers and Education, 55, 92-100.

Erez, A., \& Judge, T. (2001). Relationship of core self-evaluations to goal setting, motivation, and performance. Journal of Applied Psychology, 86(6), 1270-1279.

Gulsecen, S., \& Kubat, A., (2006). Teaching ICT to teacher candidates using PBL: A qualitative and quantitative evaluation. Educational Technology \& Society, 9 (2), 96-106.

Hockings, C., Cooke, S., Yamashita, H., McGinty, S. \& Bowl, M. (2008). Switched off: A study of disengagement among computing students at two universities. Research Papers in Education, 23(2), 191201.

Junco, R., Heiberger, G., \& Loken, E. (2010).The effect of Twitter on college student engagement and grades. Journal of Computer Assisted Learning, 27(2), 119-132.

Jick, T.D. (1979). Mixing qualitative and quantitative methods: Triangulation in action. Administrative Science Quarterly, 24(4), 602-611.

Krause, K. (2005). Engaged, inert or otherwise occupied? Deconstructing the 21st century undergraduate student. Keynote paper presented at James Cook University Symposium: Sharing Scholarship in Learning and Teaching - Engaging Students. James Cook University, QLD, Australia, 21-22 September 2005. Available online: www.griffith.edu.au/gihe

Kuh, G. (2002). The national survey of student engagement: Conceptual framework and overview of psychometric properties. Retrieved 25 June 2013 from http://nsse.iub.edu/pdf/conceptual_framework_2003.pdf

Laird, T., \& Kuh, G. (2005). Student experiences with information technology and their relationship to other aspects of student engagement. Research in Higher Education, 46(2), 211-233.

Manochehri, N., \& Sharif, K. (2010). A model-based investigation of learner attitudes towards recently introduced classroom technology. Journal of Information Technology Education: Research, 9, 31-52. Retrieved from http://www.jite.org/documents/Vol9/JITEv9p031-052Manochehri744.pdf 
Pascarella, E. T., \&Terenzini, P. T. (2005). How college affects students: Vol. 2 A third decade of research. San Francisco: Jossey-Bass.

Pitkethly, A., \& Prosser, M. (2001). The first year experience project: A model for university-wide change. Higher Education Research \& Development, 20(2), 185-198.

Tabor, S., \& Minch, R. (2013). Student adoption and development of digital learning media: Action research and recommended practices. Journal of Information Technology Education: Research, 12, 203223. Retrieved from http://www.jite.org/documents/Vol12/JITEv12ResearchP203-223Tabor1191.pdf

Wong, L. (2013). Student engagement with online resources and its impact on learning outcomes. Journal of Information Technology Education; Innovations in Practice, 12, 129-146. Retrieved from http://www.jite.org/documents/Vol12/JITEv12IIPp129-146Wong\%20FT116.pdf

Yakel, E. (2007). Digital curation. OCLC Systems \& Services, 23(4), 335-340.

Yin, R. K. (2009). Case study research: Design and methods (4th ed.). California: SAGE Publications.

\section{Biographies}

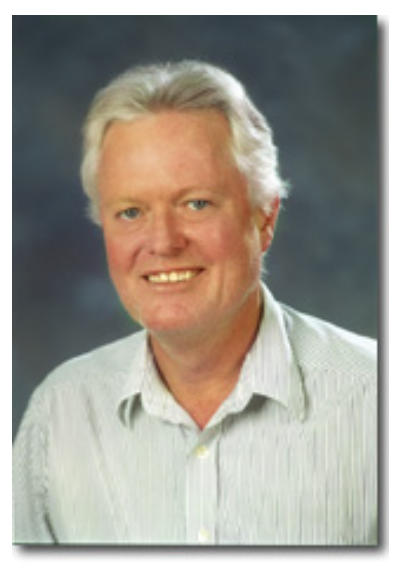

Dr. David Tuffley is a Lecturer in Applied Ethics \& Socio-Technical Studies at Griffith University's School of ICT (since 1999) and a former IT industry consultant for the 15 years before that. His research interests include Software Engineering, Leadership, Social impact of technology, Ethics in IT, Leadership of and creativity in knowledge workers.

David is the Nathan Campus First Year Student Advisor, a role primarily concerned with student engagement and retention.

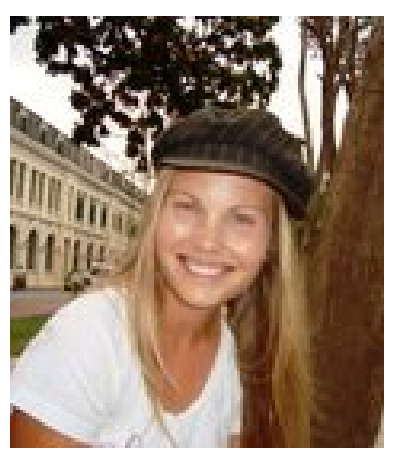

Dr. Amy Antonio is a research associate with the Australian Digital Futures Institute at the University of Southern Queensland.

Amy's research interests include social media and policy, social media in higher education, mobile technologies for student engagement, and digital curation tools to build and sustain digital communities. Amy is currently engaged in a number of research projects, including the piloting of a digital curation framework and the examination of social media usage among Australian Indigenous youth in regional and remote communities. 